\title{
SISTEM INFORMASI INVENTORY PADA YAYASAN GENERASI SEHAT INDONESIA SEHAT (SIIGESIT) TANGERANG SELATAN
}

\author{
Achyar Ibnu Hadjar1; Duwi Cahya Putri Buani² \\ ${ }^{1}$ Sistem Informasi \\ Universitas Bina Sarana Informatika \\ www.bsi.ac.id \\ tony89970@gmail.com \\ 2Teknik Informatika \\ STMIK Nusa Mandiri Jakarta \\ www.nusamandiri.ac.id \\ duwi.dcp@nusamandiri.ac.id

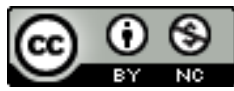

Ciptaan disebarluaskan di bawah Lisensi Creative Commons Atribusi-NonKomersial 4.0 Internasional.

Abstract-Yayasan Generasi Sehat Indonesia Sehat (GESIT) is a foundation that provides health equipment such as medicines to schools that have programs Klinik Sekolahku is a program from Yayasan GESIT. Schools are collaborating to make Yayasan GESIT need an information system that can simplify, curb the recording of inventory data, therefore an information system is created that can handle these problems. This system is called SIIGESIT or Sistem Informasi Inventory Yayasan Generasi Sehat Indonesia Sehat. SIIGESIT is designed using the RAD Model (Rapid Application Development) which is one of the software development models. The advantages of the RAD Model are that in the User Analysis stage it is involved in analyzing the needs and if the user agrees the second stage, namely the new system can be implemented so that the possibility of a miss occurs between analysts, programmers and users.

\section{Keyword: GESIT, Information Systems, RAD}

Intisari-Yayasan Generasi Sehat Indonesia Sehat (GESIT) merupakan yayasan yang menyediakan perlengakapan kesehatan seperti obat-obatan ke sekolah-sekolah yang memiliki program Klinik Sekolahku yang merupakan program dari Yayasan GESIT. Makin banyak sekolah yang berkerjasama membuat Yayasan GESIT membutuhkan sebuah sistem informasi yang dapat mempermudah, menertibkan pencatatan data inventory, oleh karena itu dibuatlah sebuah sistem informasi yang dapat menangani permasalahan tersebut. Sistem ini disebut dengan SIIGESIT atau Sistem Innformasi Inventory Yayasan Generasi Sehat Indonesia Sehat. SIIGESIT dirancang dengan menggunakan Model RAD (Rapid Aplication Development) yang merupakan salah satu dari model pengembangan perangkat lunak. Kelebihan dari Model RAD adalah pada tahapan Analisa User dilibatkan dalam menganalisa kebutuhan dan apabila user setuju tahapan yang kedua yaitu desain sistem baru dapat dilaksanakan sehingga kemungkinan terjadi miss antara analyst, programmer dan user sangat kecil.

Kata Kunci:RAD,Sistem Informasi, SIIGESIT

\section{PENDAHULUAN}

Program "Gerakan Pembangunan Berwawasan Sehat" sebagai strategi pembangunan nasional yang mempunyai arti bahwa semua program pembangunan, baik perencanaan pembangunan, maupun pelaksanaan kegiatan harus memasukkan pertimbangan kesehatan dalam penyusunan kebijakan dan program, sehingga program yang mempunyai dampak negatif terhadap kesehatan dapat dihindarkan.

Pengembangan tentang kebijakan pembangunan kesehatan dengan penerapan paradigma baru, yaitu Paradigma Sehat. Paradigma Sehat merupakan upaya meningkatkan kesehatan masyarakat yang bersifat proaktif, upaya tersebut dapat terlaksana bilamana bidang kesehatan lebih mengutamakan upaya preventif dan promotif, tanpa meninggalkan upaya kuratif dan rehabilitatif.

Seiring dengan kebijakan pembangunan kesehatan di atas, Yayasan Generasi Sehat Indonesia Sehat Indonesia Sehat (GESIT) mendukung program tersebut dengan menciptakan suatu program yang diberi nama "Klinik Sekolahku".

"Klinik Sekolahku" merupakan kerjasama antara Yayasan Gesit dengan Pihak Sekolah dalam 
bidang pelayanan kesehatan di lingkungan Sekolah. Kami berharap para Siswa/i memiliki jasmani dan rohani yang sehat.

Dengan adanya Program "Klinik Sekolahku" diharapkan dapat melahirkan Sumber Daya Manusia yang berkualitas, dimana didalam pelaksanaannya membutuhkan suatu proses yang panjang dan berkesinambungan, kami yakin program ini akan terlaksana dengan baik bila ada dukungan dari pihak - pihak yang terkait, yaitu Sekolah - Sekolah yang turut berpartisipasi dan tentunya menjadi mitra dalam program ini.

Program "Klinik Sekolahku" merupakan salah satu program dari Yayasan Generasi Sehat Indonesia Sehat (GESIT). Program ini sebagai kepedulian kami terhadap keadaan ekonomi bangsa yang kian terpuruk, daya beli masyarakat sangat rendah, sehingga masalah kesehatan pada masyarakat dikesampingkan dikarenakan biaya kebutuhan sehari - hari sangat sulit, sehingga dapat menimbulkan masalah kekurangan gizi pada anak dan kemunduran dalam intelegensia, sehingga dikhawatirkan terjadinya SDM yang rendah atau bahkan mungkin dalam 10 atau 20 tahun yang akan datang terjadi "Lost Generation".

Saat ini Yayasan GESIT mencatat data barang dalam bentuk tumpukan faktur pembelian yang memungkinkan terjadinya kehilangan data(Fiqran, Prasetyo, \& Lubis, 2015), perhitungan setiap transaksi masih menggunakan perhitungan manual(Frieyadie, 2015) sehingga memungkinkan terjadinya kesalahan(Saputra, 2016). Menghitung dan memproses data penjualan obat yang dilakukan secara konvensional(Indriani \& Sudarmadi, 2015) akan memakan banyak waktu dan tenaga, belum lagi kesalahan yang rentan terjadi(Astuti, 2011). Untuk mengolah data secara mudah, aman serta teratur serta mendapatkan hasil akhir yang akurat dibutuhkan suatu alat atau media atau sistem informasi yang dapat mengolah data dan memberikan informasi yang cepat dan akurat (Wibowo, 2009).

Sistem Informasi adalah solusi untuk permasalahan yang terjadi di Yayasan GESIT. Sistem informasi merupakan hal yang penting dalam suatu organisasi atau perusahaan. Dengan adanya sistem informasi, organisasi atau perusahaan dapat menjamin kualitas informasi yang disajikan dan dapat mengambil keputusan berdasarkan informasi tersebut(Syafarina, 2016). Dari uraian permasalahan di atas maka penulis membuat sebuah Sistem Informasi Inventory yang dapat digunakan oleh Yayasan GESIT dalam pencatatan data Obat.

\section{BAHAN DAN METODE}

Dalam penelitian ini penulis menggunakan beberapa metode pengumpulan data seperti berikut:

\section{A. Observasi}

Metode observasi yang dilakukan adalah dengan melakukan pengamatan dan penelitian secara langsung di Yayasan Generasi Sehat Indonesia Sehat(GESIT) pada bagian inventory atau persediaan obat-obatan.

\section{B. Wawancara}

Metode wawancara merupakan metode pengumpulan data yang dilakukan dengan mengadakan proses tanya jawab langsung pada Bapak Ajat Sudrajat selaku penanggung jawab pada bagian persediaan obat.

\section{Study Pustaka}

Studi pustaka merupakan metode pengumpulan data dengan cara mengumpulkan jurnal, paper dan bacaan-bacaan yang berkaitan dengan sistem inventory, membaca, serta mengenai website yang berkaitan dengan masalah yang akan dibahas dalam pembuatan laporan.

Model perangkat lunak yang digunakan dalam penelitian ini adalah model RAD(Rapid Aplication Development), ada 3 tahapan metode RAD(Rapid Aplication Development) (Noertjahyana, 2002).

\section{A. Rencana Kebutuhan (Requirement \\ Planning)}

Pada tahap ini, user dan analis melakukan semacam pertemuan untuk melakukan identifikasi tujuan dari aplikasi atau sistem dan melakukan identifikasi kebutuhan informasi untuk mencapai tujuan.

\section{B. Proses Desain (Design Workshop)}

Pada tahap ini adalah melakukan proses desain dan melakukan perbaikan-perbaikan apabila masih terdapat ketidak sesuaian desain antara user dan analis.

\section{Implementasi (Implementation)}

Setelah desain dari sistem yang akan dibuat sudah disetujui baik itu oleh user dan analis, maka pada tahap ini programmer mengembangkan desain menjadi suatu program. Setelah program selesai baik itu sebagian maupun secara keseluruhan, maka dilakukan proses pengujian terhadap program tersebut apakah terdapat kesalahan atau tidak sebelum diaplikasikan pada suatu organisasi. Pada saat ini maka user bisa 
memberikan tanggapan akan sistem yang sudah dibuat serta persetujuan mengenai sistem tersebut.

\section{HASIL DAN PEMBAHASAN}

\section{A. Rencana Kebutuhan (Requirement Planning).}

Dalam aplikasi inventory terdapat dua pengguna yang dapat saling berinteraksi dalam lingkungan sistem, yaitu: Bagian administrasi, dan Pelaksana Harian. Kedua pengguna tersebut memiliki karakteristik interaksi dengan sistem yang berbeda-beda dan memiliki kebutuhan informasi yang berbeda-beda, seperti berikut:

1) Skenario Kebutuhan Bagian Administrasi.
a) Mengelola Data Barang
b) Mengelola Data Customer
c) Mengelola Data Pemakai
d) Mengelola Data Supplier
e) Mengelola Laporan

2) Skenario Kebutuhan Pelaksana Harian.

a) Mengelola Data Transaksi Penerimaan Barang

b) Mengelola Data Transaksi Pengeluaran Barang.

\section{B. Proses Desain (Design Workshop)}

Tahapan selanjutnya dari Model RAD adalah tahapan Proses Desain. Penulis menggunakan UML (Uniferd Modeling Language) untuk mendesain sistem.

\section{1) Use Case Diagram}

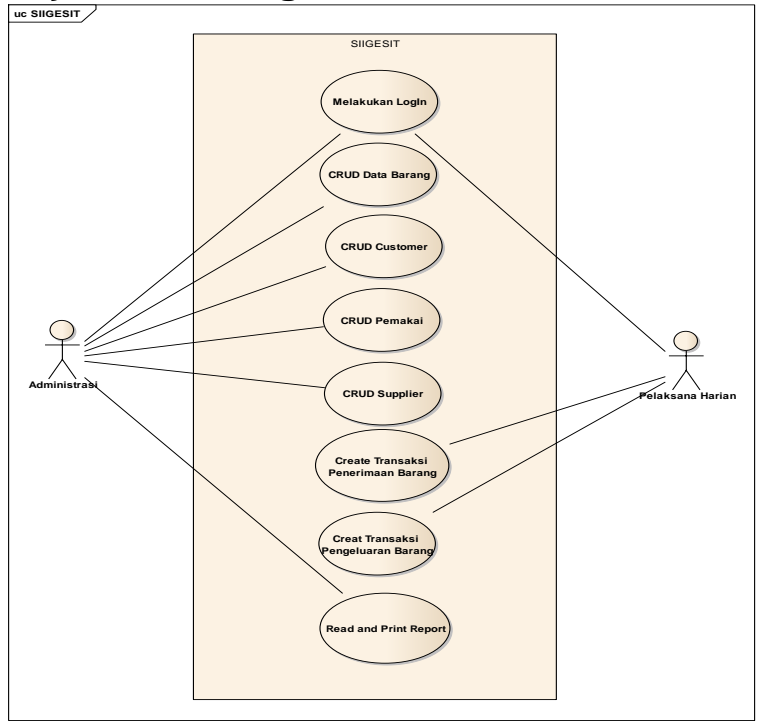

Sumber: (Hadjar \& Buani, 2019)

Gambar 1. Use Case Diagram SIIGESIT

Gambar 1 merupakan Use Case diagram yang terbentuk setelah melakukan analisa kebutuhan, dari Use Case SIIGESIT pada Gambar 1 nanti akan diimplementasikan ke dalam Bahasa pemrograman. Dari Gambar 1 juga terlihat ada dua user yang melakukan interaksi dengan SIIGESIT.

\section{2) Activity Diagram}

a) Activity Diagram LogIn

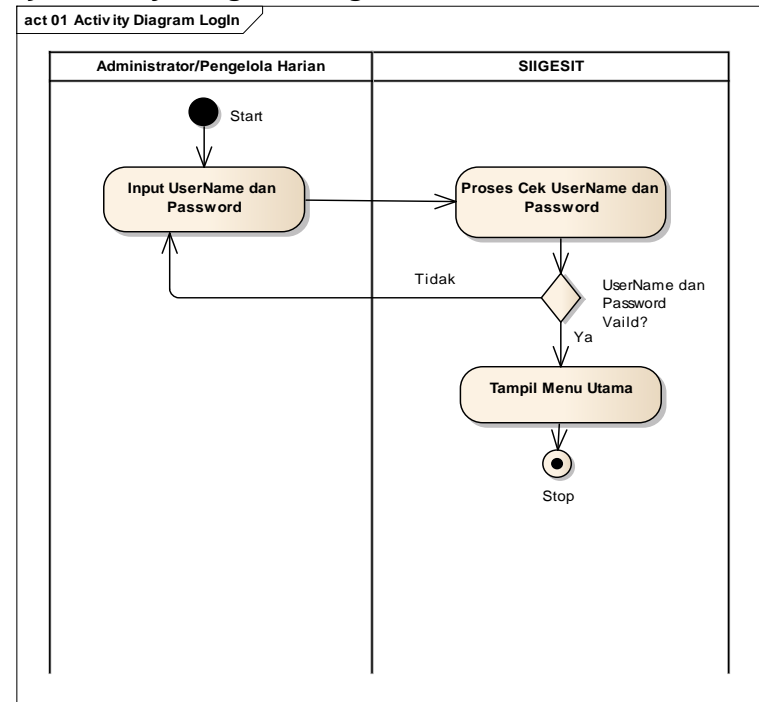

Sumber: (Hadjar \& Buani, 2019)

Gambar 2. Activity Diagram LogIn

Gambar 2 adalah gambaran dari menu login untuk masuk kedalam menu utama. Didalam menu login, user diharuskan melakukan input UserName dan Password apabila UserName dan Password tidak Valid maka user tidak dapat masuk ke dalam menu utama.

b) Activity Diagram CRUD Data Barang (Create Read Update Delete Data Barang).

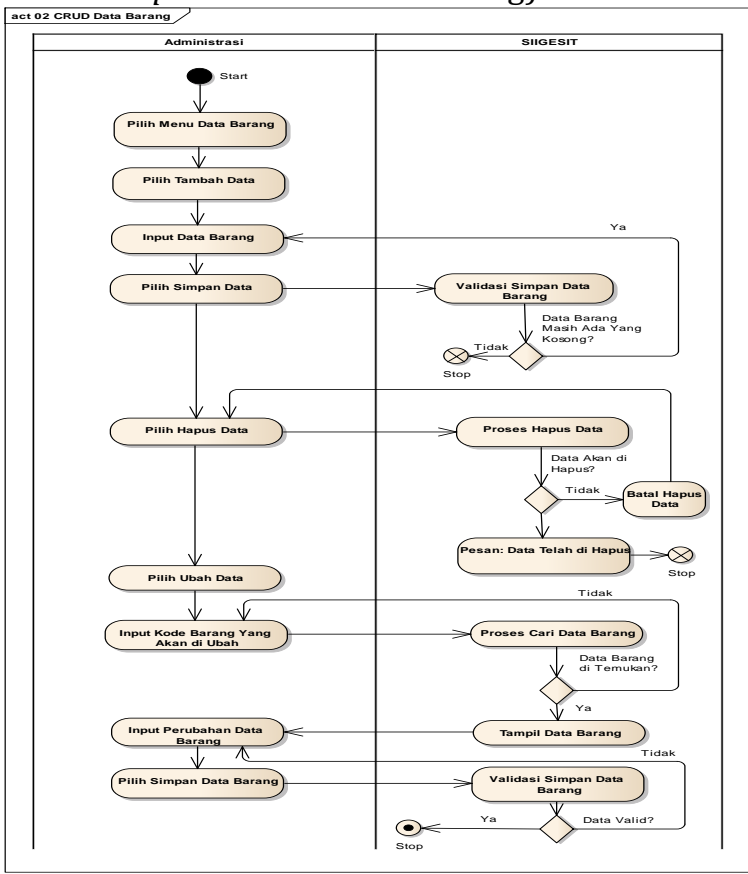

Sumber: (Hadjar \& Buani, 2019)

Gambar 3. Activity Diagram CRUD Data Barang 
Gambar 3 menujukan alur user menggunakan Menu Data Barang. Menu ini dapat diakses ketika Administrator melakukan LogIn dan Memilih Menu Data Barang. Didalam menu ini user dapat melakukan CRUD Data Barang dimana Administrator dapat melakukan Create, Read, Delete dan Update Data Barang.

c) Activity Diagram Create Transaksi Penerimaan Barang

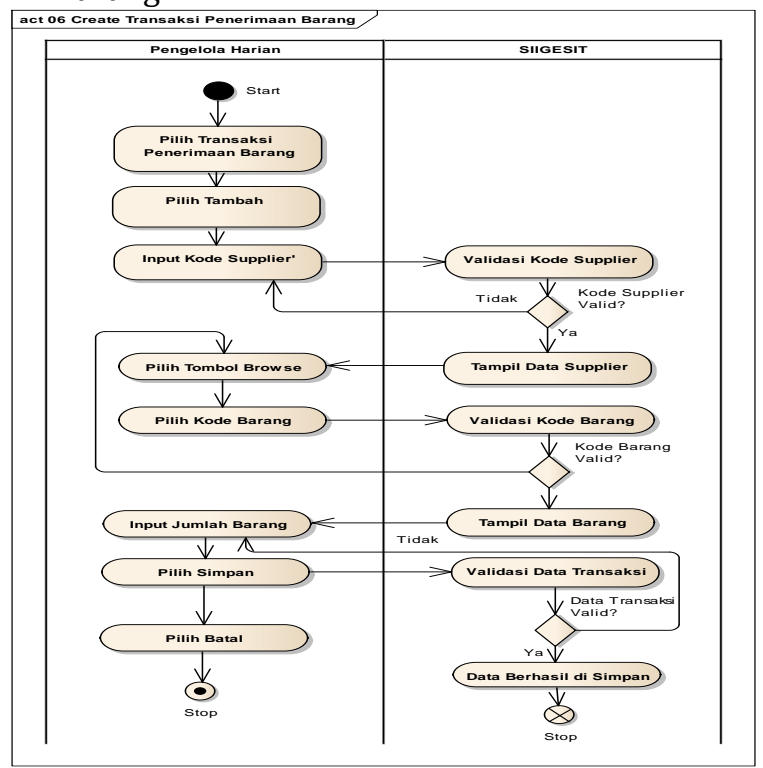

Sumber: (Hadjar \& Buani, 2019)

Gambar 7. Activity Diagram Create Transaksi Penerimaan Barang

Gambar 7 merupakan alur logika dari penggunaan menu Transaksi Penerimaan Data Barang dan yang dapat mengakses Menu ini adalah Pengelola Harian.

d) Activity Diagram Read and Print Report

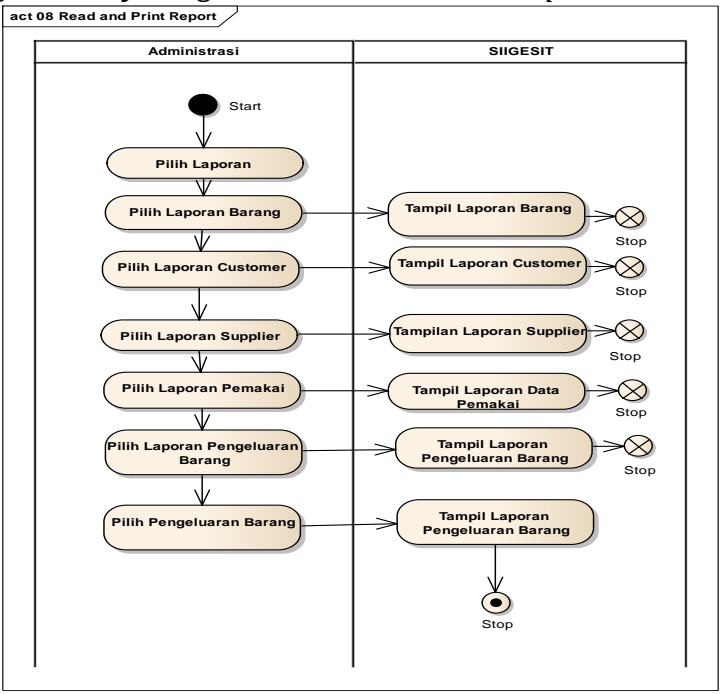

Sumber: (Hadjar \& Buani, 2019)

Gambar 9. Activity Diagram Read and Print Report
Gambar 9 merupakan alur logika dari penggunaan menu Laporan dimana dimenu laporan Administrator dapat membaca dan mencetak laporan dari data master samapi dengan data transaksi.

\section{3) Class Diagram}

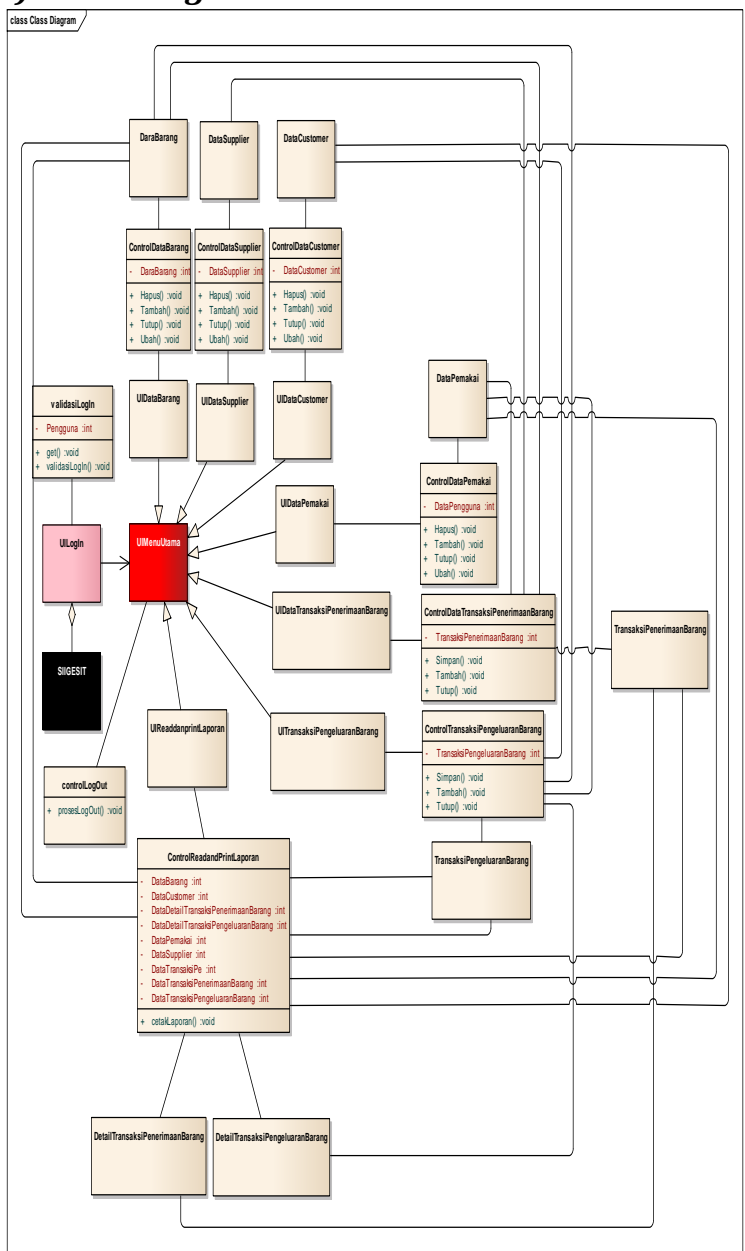

Sumber:(Hadjar \& Buani, 2019)

Gambar 10. Class Diagram SIIGESIT

Gambar 10 adalah gambaran keterkaitan antara User Interface, Control yang ada didalam Program atau Aplikasi serta attribut yang digunakan dimasing-masing user interface. Dari class diagram ini akan di generate ke dalam Bahasa pemrograman, dalam penelitian ini Bahasa pemrograman yang digunakan adalah Visual Studio 2010.

\section{4) Sequence Diagram}

Diagram ini menunjukan sebuah contoh objek dan message atau pesan yang diletakkan diantara objek-objek didalam use case diagram. 


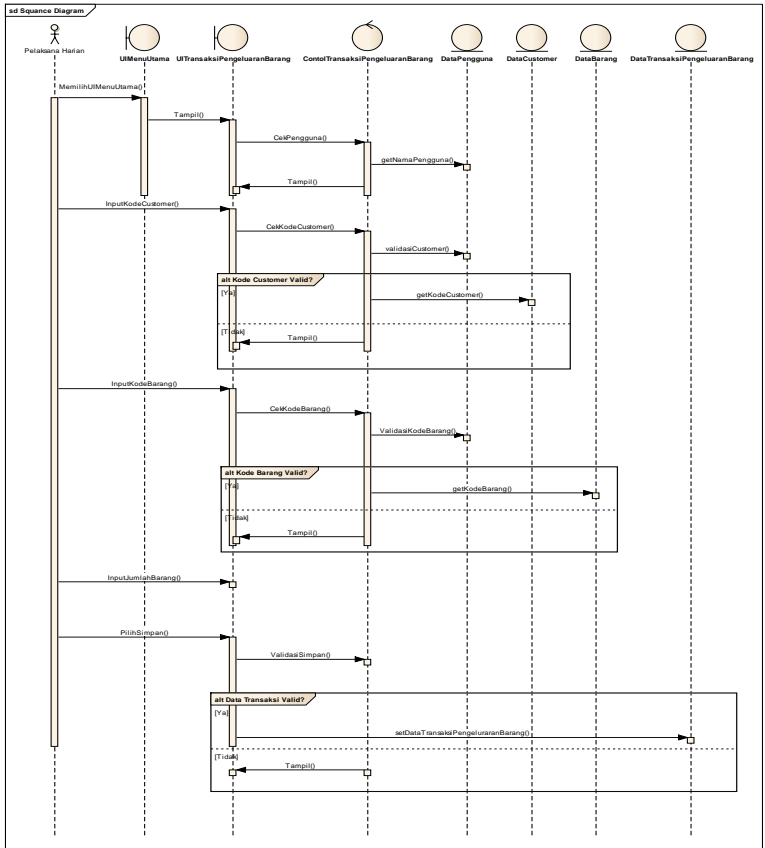

Sumber:(Hadjar \& Buani, 2019)

Gambar 11. Sequence Diagram Transaksi Pengeluaran Barang

Gambar 11 adalah Sequence Diagram Transaksi Pengeluaran Barang, Diagram Sequence menggambarkan proses dari penginputan data samapi dengan penyimpanan data, serta diagram sequence juga menunjukan attribut apa saja yang dibutuhkan dalam satu User Interface dan proses apa saja yang dapat dilakukan oleh User interface.

\section{5) Data Model}

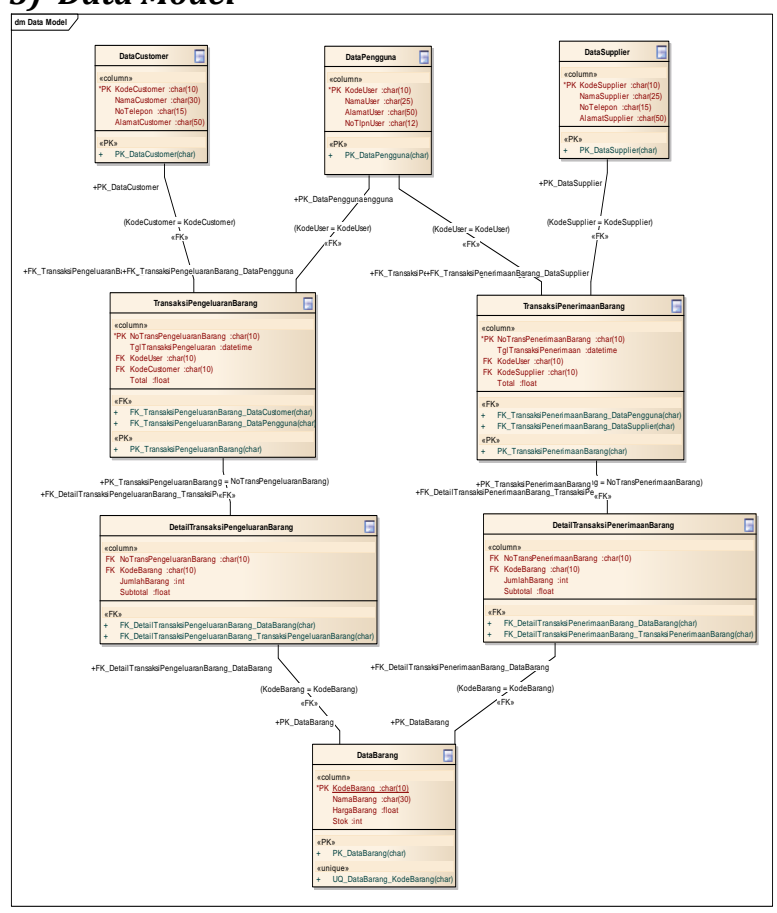

Sumber:(Hadjar \& Buani, 2019)

Gambar 12. Data Model SIIGESIT
Gambar 12 menunjukan desain database sebelum digeneret ke dalam mysql, dari data model ini selanjutnya akan digeneret ke dalam mysql untuk membentuk struktur database.

\section{6) Deployment Diagram}

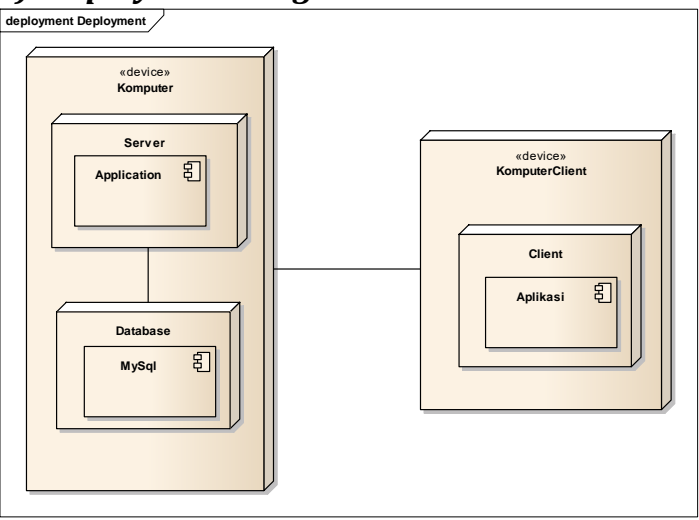

Sumber: (Hadjar \& Buani, 2019)

Gambar 13. Deployment Diagram SIIGESIT

Gambar 13 menunjukan perangkat keras dan perangkat lunak yang digunakan dalam Sistem Informasi Inventory Yayasan Generasi Sehat Indonesia Sehat.

\section{Implementasi (Implementation)}

Sistem Informasi Inventory Yayasan Generasi Sehat Indonesia Sehat implementasinya menggunakan Bahasa pemrograman Microsoft Visual Studio 2010 dan untuk pengujiannya menggunakan black box testing, berikut adalah hasil implementasi dan pengujian:

1) Implementasi

a) Form Data Barang

Form Data Barang adalah form yang digunakan untuk mengelola Data Barang, didalam form ini Administrasi dapat melakukan CRUD (Create, Read, Update dan Delete) data barang. Gambar 14 adalah Interface dari Form Data Barang.

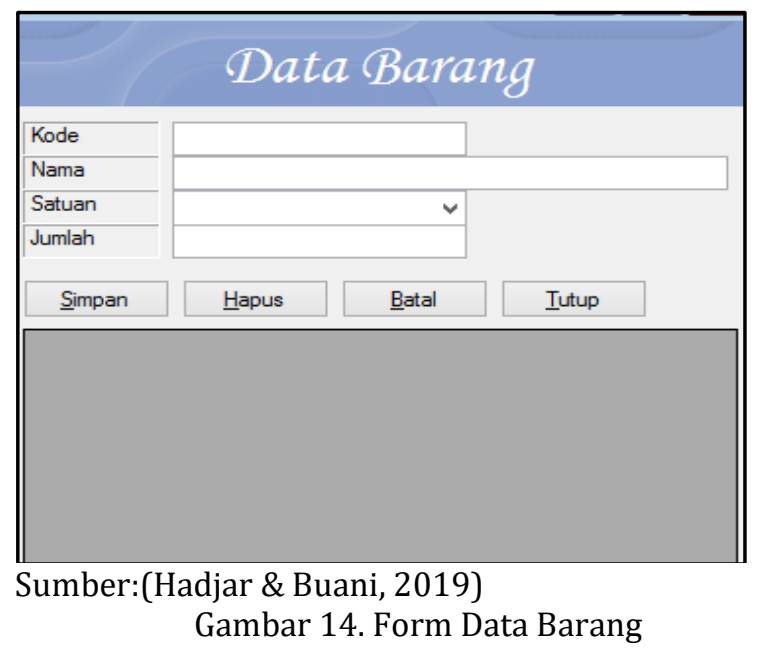


b) Form Data Pemakai Aplikasi

Form Data Pemakai Aplikasi adalah form yang digunakan untuk mengelola data user atau pengguna dari SIIGESIT, gambar 17 adalah tampilan dari form Data Pemakai Aplikasi.

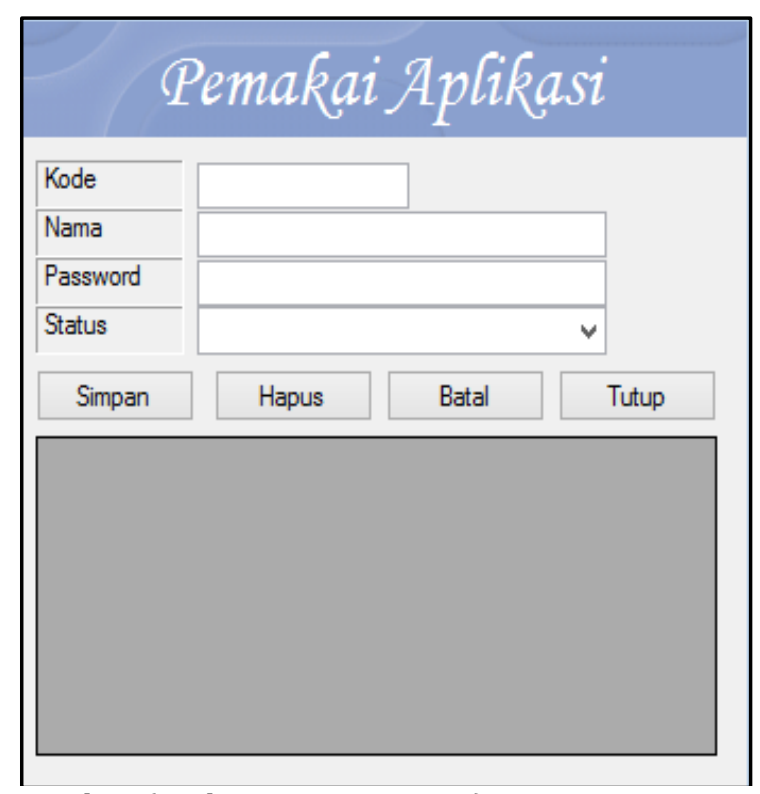

Sumber:(Hadjar \& Buani, 2019)

Gambar 17. Form Data Pemakai Aplikasi

c) Form Transaksi Penerimaan Barang

SIIGESIT adalah Sistem Informasi Inventory pada Yayasan GESIT untuk menunjang pencatatan data barang maka dibuatlah fasilitas Form Transaksi Penerimaan Barang. Fungsi dari form ini adalah untuk mencatat semua transaksi yang berhubungan dengan penerimaan barang, sehingga diharapkan Yayasan GESIT menjadi tertib administrasinya. Gamabr 18 adalah tampilan dari form Transaksi Penerimaan Barang.

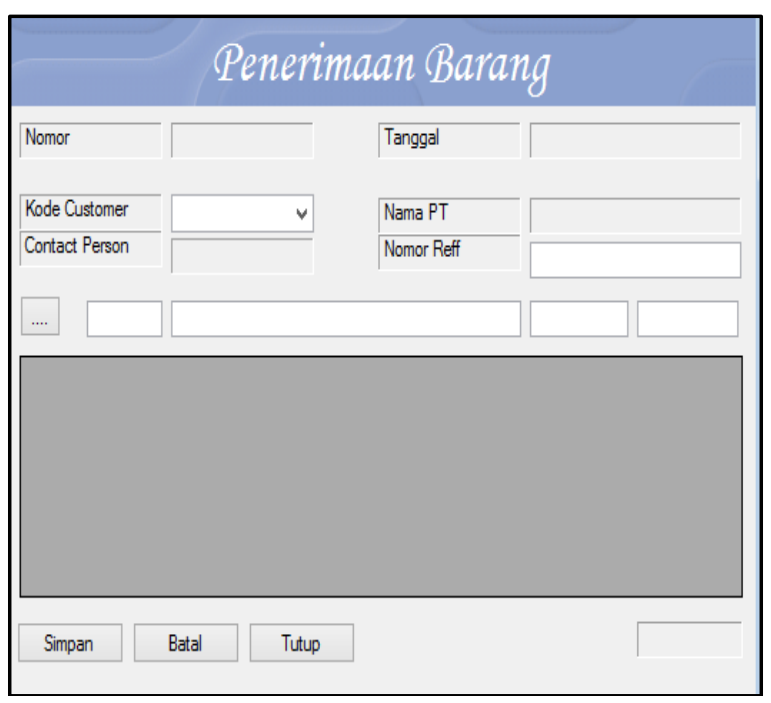

Sumber: (Hadjar \& Buani, 2019)

Gambar 18. Form Transaksi Penerimaan Barang

\section{d) Laporan}

Laporan adalah menu yang dimiliki oleh SIIGESIT, dari menu ini User dapat mencetak dan membaca laporan dari Laporan data barang sampai dengan laporan transkasi. Gambar 20 adalah contoh dari laporan data barang.

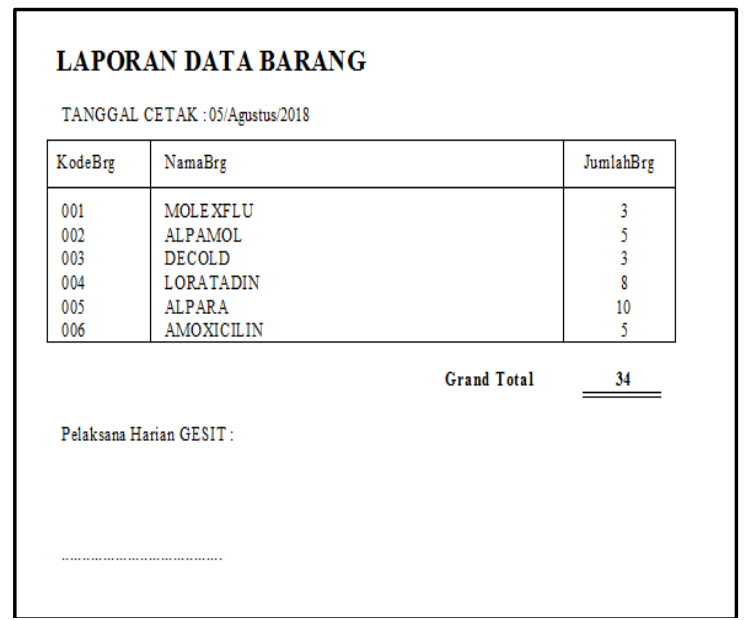

Sumber: (Hadjar \& Buani, 2019)

Gambar 20. Laporan Data Barang

e) Form LogIn

Dalam perancangan sebuah Sistem informasi diperlukan keamanan data, maka perlu sebuah hak akses untuk para user atau pengguna. Untuk mencegah terjadinya penyalah gunaan data maka dibuatlah form login. Form login akan mengelompokan user atau pengguna menjadi dua akses yaitu akses untuk administrator dan akses untuk pengelola harian. Gambar 21 menunjukan tampilan dari form login.

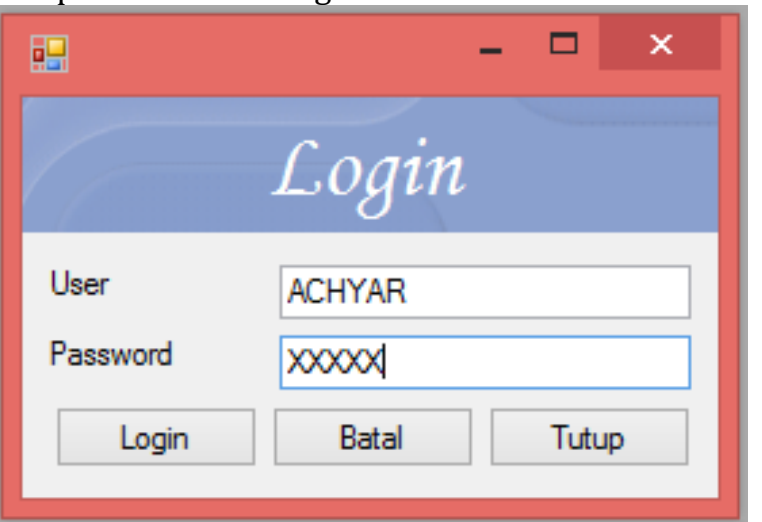

Sumber: (Hadjar \& Buani, 2019)

Gambar 21. Form LogIn

f) Form Menu Utama

Form Menu Utama adalah form yang dapat menghubungkan semua form yang ada didalam SIIGESIT form menu utama dapat diakses dengan cara melakukan login terlebih dulu. Gambar 22 adalah Form Menu Utama. 


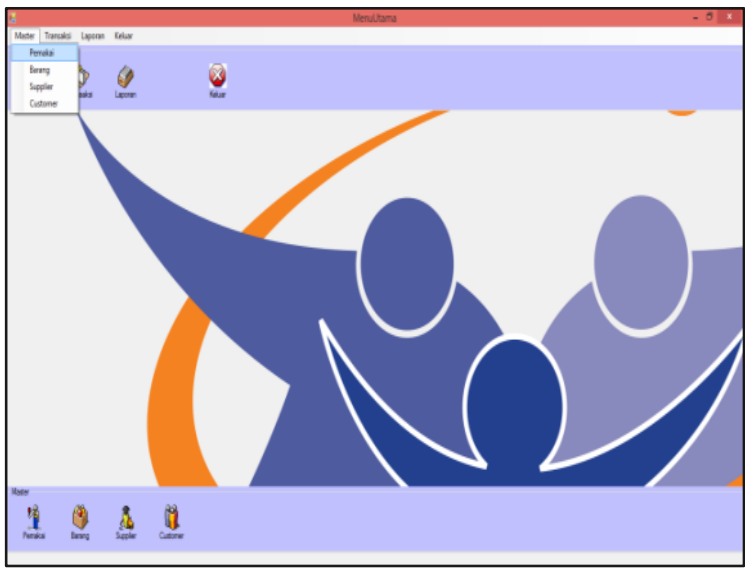

Sumber:(Hadjar \& Buani, 2019) Gambar 22. Form Menu Utama

2) Pengujian

a) Unit Testing

Table 1. Unit Testing

\begin{tabular}{|c|c|c|c|}
\hline No & Nama Form & Kondisi & Hasil \\
\hline \multirow[t]{2}{*}{1} & $\begin{array}{ll}\text { Form } & \text { Data } \\
\text { Barang } & \end{array}$ & $\begin{array}{l}\text { Data Barang } \\
\text { Masih ada yang } \\
\text { Kosong }\end{array}$ & $\begin{array}{l}\text { Mucul pesan } \\
\text { kesalaan "Data } \\
\text { Barang Masih ada } \\
\text { yang Kosong. }\end{array}$ \\
\hline & & $\begin{array}{l}\text { Harga Barang } \\
\text { dan Stok Bukan } \\
\text { Angka }\end{array}$ & $\begin{array}{l}\text { Muncul Pesan } \\
\text { Kesalahan "Harga } \\
\text { Barang dan Stok } \\
\text { tidak Valid" }\end{array}$ \\
\hline \multirow[t]{3}{*}{2.} & $\begin{array}{l}\text { Form } \\
\text { Transaksi } \\
\text { Penerimaan } \\
\text { Barang }\end{array}$ & Supplier & $\begin{array}{lr}\text { Muncul Pesan } \\
\text { Kesalahan "Id } \\
\text { Supplier tidak di } \\
\text { Kenal" }\end{array}$ \\
\hline & & $\begin{array}{l}\text { Kode } \\
\text { salah }\end{array}$ & $\begin{array}{ll}\text { Muncul } & \text { pesan } \\
\text { kesalahan } & \text { "Kode } \\
\text { Berang } & \text { tidak } \\
\text { valid" } & \\
\end{array}$ \\
\hline & & $\begin{array}{l}\text { Jumlah bukan } \\
\text { angka }\end{array}$ & $\begin{array}{l}\text { Muncul pesan } \\
\text { kesalahan } \\
\text { "Jumlah Barang } \\
\text { Harus Angka }\end{array}$ \\
\hline
\end{tabular}

Sumber: (Hadjar \& Buani, 2019)

Table 1 merupakan Unit Testing dimana setiap unit didalam program yang telah dibuat dites agar logika dan alur algoritmanya sesuai serta tidak terjadi error ketika aplikasi atau program SIIGESIT ini tayang atau sampai kepada user.

b) Sistem Testing

Table 2. System Testing

\begin{tabular}{cllll}
\hline No & \multicolumn{1}{c}{$\begin{array}{c}\text { Rencana } \\
\text { Proses }\end{array}$} & \multicolumn{2}{c}{$\begin{array}{c}\text { Hasil Yang di } \\
\text { Harapkan }\end{array}$} & Hasil \\
\hline 1. & $\begin{array}{l}\text { Klik Menu } \\
\text { Data Barang }\end{array}$ & $\begin{array}{l}\text { Membuka Form Data } \\
\text { Anggota }\end{array}$ & Sesuai \\
\hline 2. & $\begin{array}{l}\text { Klik Menu } \\
\text { Data } \\
\text { Pengguna }\end{array}$ & $\begin{array}{l}\text { Membuka Form Data } \\
\text { Pengguna }\end{array}$ & Sesuai \\
& Klik Menu & Membuka Form Data & Sesuai \\
& $\begin{array}{l}\text { Data } \\
\text { Customer }\end{array}$ & & \\
\hline 4. & Klik Menu & Membuka & FormData & Sesuai \\
& $\begin{array}{l}\text { Data } \\
\text { Supplier }\end{array}$ & Supplier & & \\
\hline
\end{tabular}

\begin{tabular}{clll}
\hline No & \multicolumn{1}{c}{$\begin{array}{c}\text { Rencana } \\
\text { Proses }\end{array}$} & \multicolumn{1}{c}{$\begin{array}{c}\text { Hasil Yang di } \\
\text { Harapkan }\end{array}$} & Hasil \\
\hline 5. & $\begin{array}{l}\text { Klik } \\
\text { Transaksi } \\
\text { Penerimaan } \\
\text { Barang }\end{array}$ & $\begin{array}{l}\text { Membuka Form } \\
\text { Penerimaan Barang }\end{array}$ & Sesuai \\
& & \\
\hline 6. & Klik & Membuka Form & Sesuai \\
& $\begin{array}{l}\text { Transaksi } \\
\text { Pengeluaran } \\
\text { Barang }\end{array}$ & Pengeluaran Barang & \\
\hline 7. & Klik Laporan & Membuka Laporan & Sesuai \\
\hline
\end{tabular}

Sumber: (Hadjar \& Buani, 2019)

Table 2 merupakan system testing dimana setiap menu didalam sistem di tes kesesuaiannya dengan rancangan sistem yang telah dibuat. Sehingga ketika diberikan kepada user aplikasi sudah sesuai dengan rancangan sistem yang telah dibuat.

\section{KESIMPULAN}

SIIGESIT merupakan sistem informasi inventory yang studi permasalahannya adalah Yayasan Generasi Sehat Indonesia Sehat, dengan adanya SIIGESIT Yayasan Generasi Sehat Indonesia Sehat mampu menertibakan pencatatan inventorynya. Model RAD(Rapid Aplication Development) dengan 3 tahapannya mempermudah peneliti dalam pembangunan SIIGESIT, dan dokumen perancangan SIIGESIT dapat terdokumentasi dengan baik. Setiap analisa SIIGESIT dilakukan melibatkan user sehingga kemungkinan terjadi miss antara perancang sistem dengan user sangat sedikit. Selain mempermudah perancangan SIIGESIT RAD juga memiliki tahapan implementasi yang didalamnya terdapat proses testing, proses testing ini dapat mengurangi kesalahan logika dari algoritma program/aplikasi hal ini dilakukan dengan unit testing, sedangkan untuk mengetes sistem agar sesuai dengan desian sistem yang dirancanag, menggunakan system testing.

\section{REFERENSI}

Astuti, P. D. (2011). Sistem Informasi Penjualan Obat Pada Apotek Jati Farma Arjosari. Journal Speed - Sentra Penelitian Engineering Dan Edukasi-, 3(4), 34-39.

Fiqran, M., Prasetyo, A., \& Lubis, B. O. (2015). SISTEM INFORMASI INVENTORY PADA PT. MASTERWEB NETWORK JAKARTA. Seminar Nasional Ilmu Pengetahuan Dan Teknologi Komputer, 177-INF.186. Retrieved from http://konferensi.nusamandiri.ac.id/prosidi ng/index.php/sniptek/article/view/329

Frieyadie, F. (2015). Pembangunan Sistem Informasi Inventory Menggunakan Linear 
Sequential Model Untuk Peningkatan Layanan Inventory Barang. Jurnal Techno Nusa Mandiri, 12(2), 104-108. Retrieved from

http://ejournal.nusamandiri.ac.id/ejurnal/in dex.php/techno/article/view/358

Hadjar, A. I., \& Buani, D. C. P. (2019). SISTEM INFORMASI INVENTORY PADA YAYASAN GENERASI SEHAT INDONESIA SEHAT (SIIGESIT) TANGERANG SELATAN. Laporan Akhir Penelitian Mandiri STMIK Nusa Mandiri Jakarta.

Indriani, K., \& Sudarmadi, . (2015). SISTEM INFORMASI INVENTORY ALAT TULIS KANTOR (ATK) MENGGUNAKAN METODE WATERFALL (Studi Kasus: Otoritas Jasa Keuangan (OJK)). Jurnal Techno Nusa Mandiri, 12(1), 69-76. https://doi.org/10.33480/TECHNO.V12I1.16 0

Noertjahyana, A. (2002). STUDI ANALISIS RAPID APLICATION DEVELOPMENT SEBAGAI PERANGKAT LUNAK Agustinus Noertjahyana. Jurnal Informatika, 3(2), 7479.

Saputra, F. (2016). PERANCANGAN DAN IMPLEMENTASI SISTEM INFORMASI INVENTORY (STUDI KASUS: TB. CIPTA KARYA), 5, 10-19.

Syafarina, G. A. (2016). PERANCANGAN APLIKASI INVENTORY BARANG MATERIALS DAN PRODUCT, 7(1), 25-33.

Wibowo, R. A. (2009). Sistem Informasi Persediaan Keluar Masuk Barang Pada Inside Distro Jakarta Rocky Aji Wibowo Universitas Surakarta. Journal Speed - Sentra Penelitian Engineering Dan Edukasi -, 1(4), 19-24. 